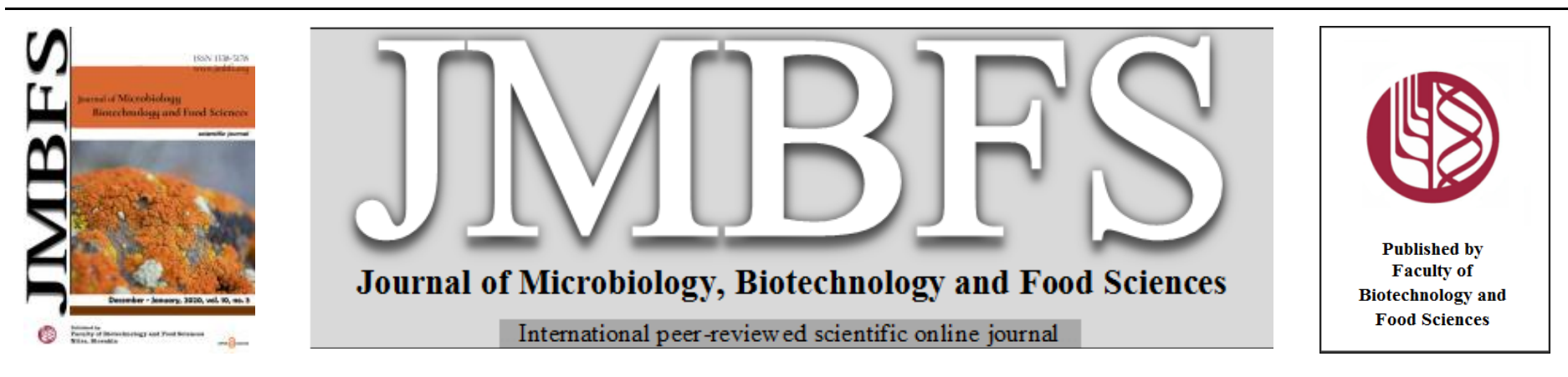

\title{
CAROTENOID AND ANTIOXIDANT RETENTION OF THE DEHYDRATED TOMATO PRODUCTS AFFECTED BY THEIR DIFFERENT TECHNOLOGICAL TREATMENTS
}

\author{
Andrea Mendelovál L'Lubomír Mendel ${ }^{2}$, Martina Fikselová3 ${ }^{3}$ Ján Mareček ${ }^{1}$
}

Address(es): doc. Ing. Andrea Mendelová, PhD.

${ }^{1}$ Department of Technology and Quality of Plant Products, Faculty of Biotechnology and Food Sciences, Slovak University of Agriculture, Tr. A. Hlinku 2, 94976 Nitra, Slovak Republic.

${ }^{2}$ National Agricultural and Food Centre, Research Institute of Plant Production, Bratislavská cesta 122, 92168 Pieštany, Slovak Republic.

${ }^{3}$ Department of Food Hygiene and Safety, Faculty of Biotechnology and Food Sciences, Slovak University of Agriculture, Tr. A. Hlinku 2, 94976 Nitra, Slovak Republic.

*Corresponding author: andrea.mendelova@uniag.sk

doi: 10.15414/jmbfs.2020.10.3.409-412

\section{ARTICLE INFO}

Received 21. 8. 2019

Revised 27. 7. 2020

Accepted 11. 8. 2020

Published 1. 12. 2020

Regular article open $\bigodot_{\text {ACCESS }}$

\begin{abstract}
Tomatoes are the most commonly preserved vegetables in the world. Traditional tomato products are tomato juice, puree or ketchup but demand for dried tomatoes is increasing at the market. Drying is one of the oldest methods of preservation and often accompanies the degradation of nutritionally important ingredients. In order to protect nutrients from excessive oxidation during drying, the right choice of the drying temperature and the treatment of the raw material prior to drying are important elements of the manufacturing process. In our work we investigated the impact of various ways of antioxidant treatment of the raw material before drying on the stability of total carotenoids, polyphenols and antioxidant activity of the product. We used Uno Rosso F1 cultivar of tomatoes, dried by air at $70{ }^{\circ} \mathrm{C}$, and the fruits were cut into slices of $3 \mathrm{~mm}$ thickness. To increase the stability of phytonutrients, we used the slice treatment prior to drying with $1 \%$ potassium bisulphite, ascorbic acid, citric and acetic acid and 5\% sucrose and sodium chloride solutions. We found that the $1 \%$ solution of ascorbic acid was the most effective in protecting of total carotenoids and polyphenols. In the protection of total polyphenols, acetic acid and potassium bisulphite solutions were equally effective. The most significant increase in antioxidant activity was found to be ascorbic acid solution.
\end{abstract}

Keywords: drying, tomato, treatment

\section{INTRODUCTION}

At the food product market, there has been an increasing demand for dried tomatoes, which are used as flavoring or decorative ingredient in food (Marfil et al., 2008). Dried tomatoes, tomato powder, as well as other processed products are subject to scientific studies due to the high antioxidant activity and high carotenoid content especially lycopene (Chang et al., 2006; Monteiro et al., 2008; Kobori et al., 2010 ).

The basic preservative principle of drying is to reduce water activity, limiting microbiological activity, enzymatic processes, and minimizing physical and chemical changes during storage of finished products (Maskan, 2000; Krokida et al., 2001).

Karam et al. (2016) report that drying is a widespread and widely used process of fruit and vegetables preserving in which the removal of water from the product minimizes the various product degradations caused either by microorganisms or by enzymes that require sufficient water content in the environment. The drying conditions as well as the method of product processing significantly affect the nutritional quality of the product, but also physical, textural and sensory properties. Traditionally, warm air drying techniques are the most widely used, which may have an adverse effect on the quality of the product, especially due to the ongoing physico-chemical changes that occur during drying in the tissues. During drying in tomatoes, changes associated with degradation of nutritionally important components, e.g. vitamin $\mathrm{C}$ and lycopene occure. Incorrect choice of drying conditions, especially low or too high temperature or too long drying time, can cause serious damage to the product, especially its taste, color and nutritional content (Doymaz, 2007; Heredia et al., 2007; Cruz et al., 2012).

Color change is most often caused by degradation of carotenoids and lycopene and also by processes of non-enzymatic browning in the reaction of sugars and amino acids in the Maillard reaction process (Marfil et al., 2008). Several authors studied the optimal drying conditions (Sacilik et al., 2006; Doymaz, 2007; Sanjinez-Argandoña et al., 2011; Doymaz a Özdemir, 2014).
Optimizing the tomato drying process can be achieved by providing maximum drying speed and minimizing oxidative and thermal damage. The prerequisite for achieving the desired quality and stability of the colors is the acceleration of the drying process due to the reduction of the cut thickness of the dried tomatoes. It is recommended the fruit to be cut into smaller pieces before drying, eg. slices, quarters. This operation will provide the larger contact area of the dried product with flowing air and will require less time to achieve the same level of moisture removal (Giovanelli et al., 2002; Sanjinez-Argandoña et al., 2011).

In order to improve the quality of dried tomatoes, it is recommended that tomatoes should be treated with calcium chloride solutions before the drying process (Lewicki et al., 2002; Lewicki and Michaluk, 2004), sodium chloride (Sacilik et al., 2006) or sodium metabisulphite (Akanbi et al., 2002; SantosSanchez et al., 2012).

Latapi and Baret (2006) report that the most widely used food additive in the drying industry is sulfur dioxide used in the gaseous state or as the sulfur dioxide salt used as a solution. Santos-Sánches et al. (2012) used the solution of $1 \%$ sodium metabisulphite in their work. The authors report that sulfur dioxide and sulphites are used as antioxidants to prevent degradation of ascorbic acid and lycopene during drying, but also during storage. Muratore et al. (2008) recommend tomatoes to be treated with a $1 \%$ citric acid solution before drying. Abreu et al. (2011) used osmotic solutions of sugar and sodium chloride at concentrations of 5 and $10 \%$ in order to increase the proportion of soluble substances in the final product and to speed up the drying process.

The aim of this study was to evaluate the efficacy of tomato slice treatment before drying with ascorbic, citric, acetic, potassium disulfite, sucrose and sodium chloride solutions for the stability of total carotenoids, total polyphenols and antioxidant activity.

\section{MATERIAL AND METHODS}

The experiment was performed using Uno Rosso F1 cultivar of tomatoes It is medium early determinate variety, suitable for mechanized harvesting. It has 
strong growth with high fertility. The fruits are small, slightly elongated, they weighs 60 - 70 grams and are resistant to cracking in more frequent rainfall and irrigation. The fruits are particularly suitable for industrial processing

Drying was performed in the laboratory oven (MEMMERT UF 160) with the possibility of controlling drying conditions, the drying temperature was $70{ }^{\circ} \mathrm{C}$ (Mendelová et al., 2014; Andrejiová and Mendelová, 2016). Drying was performed until the moisture content of the product was less than $18 \%$. The final moisture content was monitored at (KERN MRS 120-3) moisture analyzer. The average drying time was 17 hours.

We dried the fruit into slices of $3 \mathrm{~mm}$ thickness. Before drying, we used the treatment of slices with antioxidant solutions. Based on recommendations such as Latapi and Barret (2006), Hasan and El Hana (2008), Muratore et al. (2008), Abreu et al. (2011), Hasturk et al. (2011), Santos-Sánchez et al. (2012), Doymaz and Özdemir (2014), Azzez et al. (2017), we prepared: 1\% potassium metabisulphite solution, $1 \%$ ascorbic acid solution, $1 \%$ citric acid solution, $1 \%$ acetic acid solution, 5\% sucrose solution and 5\% sodium chloride solution. Treatment with solutions of organic acids and potassium metabisulphite was performed for 5 minutes, treatment with osmotic solutions for 60 minutes. After treatment, the excess moisture of the fruits was removed on the filter paper and then placed on a dryer.

The total carotenoid content was determined by the methodology of Hegedúsová et al. (2016). Sample preparation for analysis consisted of homogenization at BOSH MKN 6003 mill for 3 minutes. Carotene extraction from the homogenized samples was performed with acetone. The acetone extract obtained was shaken repeatedly with petroleum ether, and the layers were phased with distilled water. Subsequently, the carotene-saturated petroleum ether phase was dried over anhydrous sodium sulfate, transferred quantitatively to a volumetric flask and made up to the specified volume with $25 \mathrm{ml}$ petroleum ether. The absorbance of the samples was measured spectrophotometrically at JENWAY spectrophotometer (6405 UV / VIS) at $450 \mathrm{~nm}$.

The determination of total polyphenols was performed by the Folin-Ciocalteau method of Lachman et al. (2003). The method is based on the reaction of FolinCiocalteu reagent with polyphenols present in the analyzed sample to produce a blue color product. Sample preparation for polyphenol analysis consisted of homogenization and extraction in 80\% ethanol at HEIDOLPH GSL 3006 shaker at $150 \mathrm{rpm}$ for 24 hours. The polyphenol content was measured spectrophotometrically at $765 \mathrm{~nm}$ used JENWAY spectrophotometer (6405 UV /
VIS). The total polyphenols content was calculated from calibration curve (GAE) of the gallic acid at concentration $50-800 \mathrm{mg} / \mathrm{L}$.

The antioxidant activity was determined by the Phosphomolybdenum method (Prieto et al., 1999). The principle of the method is based on the reduction of Mo (VI) to Mo (V) by the reducing components of the sample and subsequent formation of the phosphate complex Mo (V) in acid $\mathrm{pH}$ with varying intensity of green color. The preparation of samples for analysis was consistent with the preparation of the sample for analysis of total polyphenols. The absorbance of the samples was measured at JENWAY (6405 UV / VIS) spectrophotometer at 695 $\mathrm{nm}$. The reducing ability of the sample was calculated from the ascorbic acid calibration curve prepared from solutions with ascorbic acid (AAE) concentrations of $40-300 \mathrm{mg} / \mathrm{L}$.

The experiment was performed in three replicates. To assess statistically significant differences among tomato variants treated before drying, we used the Tukey HSD multiple comparison test at $\mathrm{P}<0.05$.

\section{RESULTS AND DISCUSSION}

Several scientific works (Kerkhofs et al., 2005; Chang et al., 2006; SantosSánches et al., 2012; Gümüsay et al., 2015) state that in practice the most frequent air drying causes a significant decrease in nutritional quality. In order to minimize losses during such drying and improve the nutritional quality of the final product, an important technological step is the antioxidant treatment of the material prior to drying.

Based on the measured results in total carotenoid content, total polyphenol content and antioxidant activity, we found that treatment of tomato fruit before drying showed better results in all treatments and parameters than drying without pretreatment.

In terms of the overall carotenoid content assessment, ascorbic acid treatment was determined to be the most appropriate treatment method, with the highest increase in total carotenoid content (29.94 mg/100 g DM) compared to the untreated control. This claim was also supported by the results of the Tukey HSD assay, in which ascorbic acid treatment was statistically significant $(\mathrm{P}<0.05)$ the best treatment. The Tukey HSD test did not show the statistically significant difference within the effect of the remaining treatments $(1 \%$ potassium metabisulphite, $5 \%$ sodium chloride, $5 \%$ sucrose, $1 \%$ citric acid, $1 \%$ acetic acid) on total carotenoid content in dried tomato slices (Table 1).

Table 1 Means and homogeneous groups for the total carotenoid, polyphenol and antioxidant activity content at each pre-drying treatment based on multiple comparison from the Tukey HSD test

\begin{tabular}{lccc}
\hline Treatment & $\begin{array}{c}\text { Total carotenoid content } \\
(\mathrm{mg} / 100 \mathrm{~g} \mathrm{DM})\end{array}$ & $\begin{array}{c}\text { Total polyphenol content } \\
(\mathrm{mg} \mathrm{GAE} / 100 \mathrm{~g} \text { DM })\end{array}$ & $\begin{array}{c}\text { Antioxidant activity } \\
(\mathrm{mg} \text { AAE/100 g) DM }\end{array}$ \\
\hline control (no treatment) & $126.85 \pm 0.29 \mathrm{a}$ & $204.44 \pm 6.93 \mathrm{a}$ & $351.37 \pm 16.59 \mathrm{a}$ \\
citric acid 1\% & $130.33 \pm 0.42 \mathrm{ab}$ & $218.90 \pm 4.22 \mathrm{ab}$ & $388.05 \pm 0.29 \mathrm{~b}$ \\
sucrose 5\% & $134.79 \pm 0.40 \mathrm{ab}$ & $226.35 \pm 5.44 \mathrm{bc}$ & $411.22 \pm 10.15 \mathrm{bc}$ \\
sodium chloride 5\% & $143.92 \pm 0.08 \mathrm{ab}$ & $234.55 \pm 2.75 \mathrm{c}$ & $419.04 \pm 6.79 \mathrm{bc}$ \\
acetic acid 1\% & $151.42 \pm 2.26 \mathrm{ab}$ & $235.36 \pm 4.11 \mathrm{~cd}$ & $430.21 \pm 5.24 \mathrm{c}$ \\
potassium metabisulphite 1\% & $152.43 \pm 17,64 \mathrm{ab}$ & $235.38 \pm 7.25 \mathrm{~cd}$ & $434.29 \pm 15.59 \mathrm{c}$ \\
ascorbic acid 1\% & $156.79 \pm 19.53 \mathrm{~b}$ & $250.25 \pm 6.87 \mathrm{~d}$ & $540.98 \pm 20.47 \mathrm{~d}$ \\
\hline
\end{tabular}

- different letters at mean represent statistically significant differences among treatments $(\mathrm{P}<0.05)$

By evaluating the total polyphenol content we found, similarly to the total carotenoid content, statistically significant $(\mathrm{P}<0.05)$ the highest total polyphenol content after treatment with $1 \%$ ascorbic acid (250.25 mg GAE/100 g DM). Compared to the control sample with no treatment (204.44 mg GAE/100 g DM), it is the highest difference (45.81 mg GAE/100 g DM). There were statistically significant $(\mathrm{P}<0.05)$ different 11 test pairs. Treatment with $1 \%$ ascorbic acid was not statistically significant different $(\mathrm{P}>0.05)$ comparing to the treatment with $1 \%$ acetic acid and $1 \%$ potassium metabisulphite (Table 1 ).

Treatments with $1 \%$ citric acid solution and 5\% sodium chloride solution were evaluated to be the less effective treatments for polyphenol protection. Treatment with $5 \%$ sucrose solution (218.90 mg GAE/100 g DM) was not statistically significant $(\mathrm{P}>0.05)$ different from the untreated control sample $(204.44 \mathrm{mg}$ $\mathrm{GAE} / 100 \mathrm{~g} \mathrm{DM}$ ) in total content polyphenols in dried tomato slices.

As the statistically significant $(\mathrm{P}<0.05)$ the most effective in antioxidant protection was the solution of $1 \%$ ascorbic acid again. Ascorbic acid is considered to be the significant antioxidant, it increased the antioxidant potential of dried tomatoes, that can be seen on the high antioxidant activity (540.98 mg AAE/100 g DM). Based on the one-way ANOVA and post-hoc Tukey HSD tests, it can be concluded that all 5 pre-drying treatments applied showed the statistically significant $(\mathrm{P}<0.05)$ positive effect on antioxidant activity of dried tomato slices (Table 1).

Table 1 shows positive effect of the individual treatments on the antioxidant activity of the dried slices. Relatively similar in antioxidant protection of dried tomato slices were solutions of potassium metabisulphite, acetic acid, sodium chloride and citric acid, among which we did not find any statistically significan difference $(\mathrm{P}>0.05)$. Statistically significant $(\mathrm{P}<0.05)$ the lowest effect in antioxidant protection showed the sucrose solution (388.05 mg AAE/100 g DM), but even this solution showed no statistically different $(\mathrm{P}<0,05)$ results compared to the citric acid solution (411.22 $\mathrm{mg}$ AAE/100 $\mathrm{g}$ DM) and sodium chloride (419.04 mg AAE/100 g DM).

Muratore et al. (2008) investigated the effect of drying and treatment temperature on changes in lycopene, $\beta$-carotene and ascorbic acid, during drying at various temperatures as well as the effect of fruit treatment prior to drying. Cherry tomato fruits were treated with $1 \%$ sodium chloride solution and $1 \%$ citric acid prior to drying. Drying was performed at 40,60 and $80^{\circ} \mathrm{C}$. They dried the samples to the relatively high residual moisture up to $40 \%$ and named the product as semi-dry cherry tomatoes. They found that the temperature of $80{ }^{\circ} \mathrm{C}$ was the most suitable for the stability of lycopene and $\beta$-carotene for both untreated and treated samples. The fresh sample contained $99.8 \mathrm{mg} / 100 \mathrm{~g} \mathrm{DM}$ of lycopene, and only $58.5 \mathrm{mg}$ of $100 \mathrm{~g}^{-1} \mathrm{DM}$ was retained in $40^{\circ} \mathrm{C}$ dried sample and in the sample dried at $80^{\circ} \mathrm{C}, 76.4 \mathrm{mg} / 100 \mathrm{~g} \mathrm{DM}$. In the treated samples, the authors did not find significantly higher contents of lycopene or $\beta$-carotene compared to untreated samples. However, the positive effect of the treatment was shown in relation to ascorbic acid. In the fresh sample of tomatoes, they detected 433.5 $\mathrm{mg} / 100 \mathrm{~g} \mathrm{DM}$, in the untreated sample dried at $40{ }^{\circ} \mathrm{C}$, the ascorbic acid content was $311.5 \mathrm{mg} / 100 \mathrm{~g} \mathrm{DM}$ and in the treated sample $368.1 \mathrm{mg} / 100 \mathrm{~g} \mathrm{DM}$.

Abreu et al. (2011) used 5 and $10 \%$ osmotic solutions of sucrose and sodium chloride as well as various combinations prior to tomato drying. They used Bonus variety, the treatment with osmotic solutions was performed for 120 minutes, followed by drying at $65{ }^{\circ} \mathrm{C}$ for 12 hours. Treatment with osmotic solutions after drying resulted in the higher soluble dry matter content, especially in solutions with $10 \%$ sucrose content. They found interesting results in the evaluation of lycopene retention in dried samples. Sucrose solution showed the best results. After treatment with this solution, they detected an increase in the lycopene content in the sample by $5.63 \%$. The lycopene content increased from $446.85 \mu \mathrm{g} / \mathrm{g}$ DM to $472.02 \mu \mathrm{g} / \mathrm{g}$ DM. $10 \%$ sucrose solution and $5 \%$ sodium chloride solution were also found to be suitable solutions for treating of tomatoes 
prior to drying to improve lycopene stability. In the case of $10 \%$ sucrose solution, the lycopene content after drying was $43.5 \%$ higher than in the control sample and $34.1 \%$ in the case of $5 \%$ sodium chloride solution. In our work, comparing to $5 \%$ solution of sucrose and $5 \%$ sodium chloride solution, we found better results with sodium chloride solution in relation to the stability of total carotenoids, even though it is far from being such a high retention percentage as reported by the authors. In case of $5 \%$ sodium chloride solution, the total carotenoid content was higher by $13.8 \%$ compared to the control sample and $6.8 \%$ by the $5 \%$ sucrose solution.

Hastur Sahim et al. (2011) compared the effect of different ways of drying in tomato slices: in the sun, in a hot air dryer at 65,75 and $85^{\circ} \mathrm{C}$ under vacuum, by lyophilization and also by treatment before drying with $1 \%$ ascorbic acid $+1 \%$ citric acid $+4 \%$ potassium carbonate solution $+2 \%$ sodium metabisulphite on the stability of lycopene and the color properties of dried tomatoes. Authors found that treatment with the prepared solution showed the positive effect on the retention of lycopene in dried tomatoes in all hot air drying processes as well as in vacuum drying and lyophilization. By evaluation of the drying in a hot-air dryer as the most commonly used drying method in practice, the drying at $65^{\circ} \mathrm{C}$ after the previous treatment the highest stability of lycopene was positively evaluated.

Latapi and Barret (2006a) dried tomatoes in direct sunlight at an average daily temperature of $30{ }^{\circ} \mathrm{C}$ for 9 days. In order to protect the nutritionally importan components, they treated tomatoes before drying with $10 \%$ sodium chloride solution, $8 \%$ sodium metabisulphite solution and solution obtained by mixing of a basic solution of sodium chloride and potassium metabisulphite. They showed positive effect on the stability of lycopene, not only during the drying process, but also during the subsequent storage of the finished products. By assessing the impact on the stability of ascorbic acid, authors noted the inadequate effect of the solutions used, as the ascorbic acid content of the dried samples decreased from the original value of $3.37 \mathrm{mg} / \mathrm{g}$ to less than $0.4 \mathrm{mg} / \mathrm{g}$ in the treated samples. With only sodium chloride treatment, ascorbic acid content was reduced by $97.3 \%$, almost to zero content.

Doymaz and Özdemir (2014) treated tomatoes with 3\% potassium carbonate solution and $2 \%$ solution of oleic acid and ethanol. They used the drying temperature of 60,68 and $76{ }^{\circ} \mathrm{C}$, and the tomatoes were cut in half, quarter and eighth. In their conclusions they note the positive effect of the drying temperature and the fruit treatment before drying on the drying rate.

\section{CONCLUSION}

Based on the results, we can conclude that all pre-drying treatments used, showed positive effect on the resulting nutritional quality of the dried tomato slices. In assessing the effect of treatment on carotenoid stability, we found the highes total carotenoid content after treatment with $1 \%$ ascorbic acid solution, but based on the results of the Tukey test, this treatment was not statistically significant (P> 0.05) compared remaining treatments. By evaluating the effect of the pre-drying treatment on the stability of the total polyphenol content, treatment with $1 \%$ ascorbic acid solution was the most effective treatment, but $1 \%$ acetic and potassium metabisulphite solutions were equally effective, with no statistically significant difference ( $\mathrm{P}>0.05)$. The weakest effect on polyphenol stability showed the $5 \%$ sucrose solution.

The ascorbic acid solution was also proven to be effective as pre-drying treatmen regarding the antioxidant activity, and contributed to increasing the antioxidant potential of dried tomato slices as well. Less effective than $1 \%$ ascorbic acid solution appeared to be $1 \%$ acetic acid solution and $1 \%$ potassium metabisulphite solution as in the case of polyphenol protection, with no statistical difference The decreasing gradient in the antioxidant protection effect during drying showed solutions of sodium chloride, citric acid and sucrose, among which we found no statistically significant $(\mathrm{P}>0.05)$ difference.

Acknowledgement This research was supported by KEGA 044SPU-4/2019 and KEGA 017SPU-4/20019.

\section{REFERENCES}

ABREU, W. C., BARCELOS, M. F. P., SILVA, E. P., BOAS, E. V. B. E. 2011 Physical and chemical characteristics and lycopene retention of dried tomatoes subjected to different pre-treatments. Revista do Instituto Adolfo Lutz, 70(2), 168 174. ISSN 1983-3814

AKANBI, C. T., ADEYEMI, R. S., OJO, A. 2006. Drying characteristics and sorption isotherm of tomato slices. Journal of Food Engineering, 73(2), 157-163. http://dx.doi.org/10.1016/j.jfoodeng.2005.01.015

ANDREJIOVÁ, A., MENDELOVÁ, A. 2016. Vplyv diferencovanej výživy a spracovania na obsah vybraných bioaktivnych látok $v$ plodoch rajčiaka jedlého (Lycopersicon esculentum Mill.). 1. vyd. Nitra : Slovenská pol'nohospodárska univerzita, 79 s. ISBN 978-80-552-1605-8.

AZEEZ, L., OEDEJI, A. O., ADEBISI, S. A., ADEJUMO, A. L., TIJANI, K. O 2017. Chemical components retention and modelling of antioxidant activity using neural networks in oven dried tomato slices with and without osmotic dehydration pre-treatment. Journal of Food Measurement and Characterization 11(4), 2247-2258. https://doi.org/10.1007/s11694-017-9609-z

GIOVANELLI, G., ZANONI, B., LAVELLI, V., NANI, R. 2002. Water sorption, drying and antioxidant properties of dried tomato products. Journal of Food Engineering, 52(2), 135-141. http://dx.doi.org/10.1016/S0260$\underline{\text { 8774(01)00095-4 }}$

GÜMÜSAY, O. A., BORAZAN, B. A., ERCAL, N., DEMIRKOL, O. 2015 Drying effects on the antioxidant properties of tomatoes and ginger. Food Chemistry, 173, 156-162. http://dx.doi.org/10.1016/i.foodchem.2014.09.162

HASAN, N., EL HANA, A. 2008. Drying kinetics of osmotically-treated tomatoes. Misr Journal of Agricultural Engineering, 25(3), 957-979. ISSN 1687384.

HASTURK SAHIN, F., AKTAS, T., ORAK, H., ULGER, P. 2011. Influence of pretreatments and different drying methods on color parameters and lycopene content of dried tomato. Bulgarian Journal of Agricultural Science, 17(6), 867 881. ISSN 1310-0351

HEGEDÜSOVÁ, A., MEZEYOVÁ, I., ANDREJIOVÁ, A. 2016. Metódy stanovenia vybraných biologicky aktívnych látok. Nitra : Slovenská pol'nohospodárska univerzita, $75 \mathrm{~s}$. ISBN 978-80-552-1420-7.

HEREDIA, A., BARRERA, C., ANDRES, A. 2007. Drying of cherry tomato by a combination of different dehydration techniques. Comparison of kinetics and other related properties. Journal of Food Engineering, 80(1), 111-118. https://doi.org/10.1016/j.jfoodeng.2006.04.056

CHANG, C. H., LIN, H., CHANG, C., LIU, Y. 2006. Comparisons on the antioxidant properties of fresh, freeze-dried and hot-air-dried tomatoes. Journal of Food Engineering, 77(3), 478-485 http://dx.doi.org/10.1016/i.jfoodeng.2005.06.061

KARAM, M. C. E., PETIT, J., ZIMMER, D., DJANTOU, E. B., SCHER, J. 2016. Effects of drying and grinding in production of fruit and vegetable powders: a review. Journal of Food Engineering, 188, 32-49. https://doi.org/10.1016/j.jfoodeng.2016.05.001

KERKHOFS, N. S., LISTER, C. E., SAVAGE, G. P. 2005. Change in Colour and Antioxidant Content of Tomato Cultivars Following Forced-Air Drying. Plant Foods for Human Nutrition, 60(3), 117-121. https://doi.org/10.1007/s11130-005-6839-8

KOBORI, C. N., HUBER, L. S., KIMURA, M., RODRIGUEZ-AMAYA, D. B. 2010. Teores de carotenoides em produtos de tomate. Revista Instituto Adolfo Lutz, 69(1), 78-83. ISSN 0073-9855

KROKIDA, M. K., MAROULIS, Z. B., SARAVACOS, G. D. 2001. The effect of the method of drying on the colour of dehydrated products. International Journal of Food Science + Technology, 36(1), 53-59. https://doi.org/10.1046/j.1365-2621.2001.00426.x

KROKIDA, M. K., TSAMI, E., MAROULIS, Z. B. 1998. Kinetics on color change during drying of some fruit and vegetables. Drying Technology, 16, 667 685. http://dx.doi.org/10.1080/07373939808917429

LACHMAN, J., PRONĚK, D., HEJTMÁNKOVÁ, A., PIVEC, V., FAITOVÁ, K. 2003. Total polyphenol and main flavonoid antioxidants in different onion (Allium cepa L.) varieties. Scientia Horticulturae, 30, 142-147. ISSN 1805-9333 LATAPI, G., BARRETT, M. 2006. Influence of pre-drying treatments on quality and safety of sun-dried tomatoes. Part I: use of steam blanching, boiling brine blanching, and dips in salt or sodium metabisulfite. Journal of Food Science, 71(1), 24-31. https://doi.org/10.1111/j.1365-2621.2006.tb12401.x

LEWICKI, P. P., LE, H. V., POMARANSKA-LAZUKA, W. 2002. Effect of pretreatment on convective drying of tomatoes. Journal of Food Engineering, 54(2) 141-146. http://dx.doi.org/10.1016/S0260-8774(01)00199-6

LEWICKI, P. P., MICHALUK, E. 2004. Drying of tomato pre-treated with calcium. Drying Technology, 22(8), 1813-1827. http://dx.doi.org/10.1081/DRT200032777

MARFIL, P. H. M., SANTOS, E. M., TELIS, V. R. N. 2008. Ascorbic acid degradation kinetics in tomatoes at different drying conditions. LWT- Food $\begin{array}{llll}\text { Science } \quad \text { and } & \text { Technology, } & \text { 1642-1647. }\end{array}$ http://dx.doi.org/10.1016/j.lwt.2007.11.003

MASKAN, M. 2000. Kinetics of colour change of kiwifruits during hot air and microwave drying. Journal of Food Engineering, 48(2), 169-175 http://dx.doi.org/10.1016/S0260-8774(00)00154-0

MENDELOVÁ, A., MENDEL, L., FIKSELOVÁ, M., CZAKO, P. 2014. Effect of drying temperature on lycopene content of processed tomatoes. Potravinárstvo, 7(1), 141-145. ISSN 1337-0960. http://dx.doi.org/10.1007/s11101-007-9085-x. MONTEIRO, C. S., BALBI, M. E., MIGUEL, O. G., PENTEADO, P. T. P. S. HARACEMIV, S. M. C. 2008. Qualidade nutricionale antioxidante do tomate "tipo italiano". Alimentos e Nutrição Araraquara, 19(1), 25-31. ISSN 0103-4235 MURATORE, G., RIZZO, V., LICCIARDELLO, F., MACCARONE, E. 2008 Partial dehydration of cherry tomato at different temperature, and nutritional quality of the products. Food Chemistry, 111, 887-891. https://doi.org/10.1016/j.foodchem.2008.05.001

PRIETO, P., PINEDA, M., AQUILAR, M. 1999. Spectrophotometric quantification of antioxidant capacity though the formation a phosphomolybdenum complex. Analytical Biochemistry, 269, 337-341. https://doi.org/10.1006/abio.1999.4019 
SABLANI, S. S. 2006. Drying of fruits and vegetables: retention of nutritional/functional quality. Drying technology, 24(2), 123-135. http://dx.doi.org/10.1080/07373930600558904

SACILIK, K., KESKIN, R., ELICIN, A. K. 2006. Mathematical modeling of solar tunnel drying of thin layer organic tomato. Journal of Food Engineering, 73(3), 231-238. http://dx.doi.org/10.1016/j.jfoodeng.2005.01.025

SHI, J. X., LE MAGUER, M., KAKUDA, Y., LIPTAY, A., NIEKAMP, F. 1999. Lycopene degradation and izomerization in tomato dehydration. Food Research International, 32(1), 15-21. http://dx.doi.org/10.1016/S0963-9969(99)00059-9 